Eurasia: Economics \& Business, 2(44), February 2021

DOI https://doi.org/10.18551/econeurasia.2021-02

UDC 332

\title{
WHAT DRIVES INDONESIAN ADOLESCENT GAMERS BUYING VIRTUAL PRODUCT WITHIN LEISURE DURING PANDEMIC? IMMERSION VERSUS TELEPRESENCE
}

\author{
Bafadhal Aniesa Samira* \\ Department of Tourism, Univerity of Brawijaya, Indonesia \\ Hendrawan Muhammad Rosyihan \\ Department of Library and Information Science, Univerity of Brawijaya, Indonesia \\ *E-mail: aniesa.bafadhal@ub.ac.id
}

\begin{abstract}
Various aspects of online video games and its systemic impact on society during COVID 19 outbreak especially in adolesecent behaviour have become part of modern subcultures at the global level and are an attractive industry to look at from leisure and business. This research model was adopted based on the Technology Acceptance Model (TAM) 2 and 3, and the Unified Theory of Acceptance and Use of Technology (UTAUT) which states that the experience will affect the behavioral intention of technology users. This research using Partial Least Square (PLS) to analyze the effect of virtual experiences consisting of the ability of online video games to provide feelings of immersion and telepresence towards the intention to buy virtual products by 116 adolescents which is Multiplayer Online Battle Arena (MOBA) gamers in Indonesia. The results show that the game developer and game company need to consider the ability of the game to provide quality of psycological presence (telepresence) because it has been confirmed in this research that it is proven to be able to encourage the intention to buy virtual product. But, the graphics and physical presence (immersion) of the MOBA game are not necessary affect the consumer behaviour in-game.
\end{abstract}

\section{KEY WORDS}

Virtual experience, immersion, telepresence, intention to buy, virtual product.

There has been a drastic shift in how adolescents spend their free time in the last decade. Adolescents tend to interact directly with peers outside the home, but at the moment, they overall spend more time at home and playing indoors (Karsten, 2005; Carver et al., 2010). Some logical reasons arise because of parent restrictions (Kepper, 2020), limited public space (Kyttä, 2004), busy parent work hours (Jurzcyk \& Lange, 2007), trends in urban apartment house (Boterman et al., 2010), crime and safety (Clements, 2004), traffic (Björklid \& Nordström, 2007), and current health issues related home-quarantined during COVID 19 pandemic (Tull et al., 2020; Saurabh \& Ranjan, 2020) also plays an important role for making in-home activities becomes more and more popular among adolescents.

No doubt that locked up at home for so long time, especially during pandemic makes million people bored, stressed, and have a lot of leisure. However, the lives of today's adolescence are also very different from previous generations where access to virtual environments allows them to still interact with peers (Kuntsche et al., 2009). As much more human activities are moving to the virtual world, so virtual world was become a reflection and simulacrum of modern society. Advanced internet, computer and technology developments keep our bodies at home but being able to senses, act, interact and wander omnipresence at the same time.

Video games tend to be associated with negative image activities. On the other hand, during a pandemic gamers actually get benefit from playing video games. Therefore, the majority of adolescents now recognize playing video games as a leisure activity (Olson et al., 2007; Brooks et al., 2015). Gaming popularity has grown rapidly and distinctive feature of the leisure pursuits of the current adolescents generation (Olson, 2010) Online video games becomes a perfect social platform to escapism, comfort, keep social interaction with others to 
get rid of the loneliness throughout pandemic (Zhu, 2020). Altough in general online video games are designed for a wide range of ages, adolescents played slightly more than adults (Griffiths et al., 2004) and not suprising if more males play online video games than female (Kuss \& Griffiths, 2012). Urban adolescents are familiar to filling their spare time with various types of games developed in online video games including strategic planning, fantasy, sports, shooting and racing (Bilgihan et al., 2013) with magnificent graphics, realistic and powerfull persona, resembles real images or even hyperealities, and cutting edge game systems and enable absorbed in a game using a console, a PC, a smartphone or any immersive devices.

In the midst of these conditions it cannot be denied that the video game industry has become a significant sector of the economy. Denegri-Knott and Moleswoth (2010) conceptualize consumer behavior in the digital field in relation to virtual consumers. Research results from López-Cabarcos et al. (2020) show that during the COVID-19 outbreak, making gaming company monetization superior throughout the first half of 2020, the high demand for game products and their derivatives such as in-game virtual products affected the returns and financial health of the gaming industry. better than other industries. Eventbrite (2014) showed that $47 \%$ of gamers claimed to buy game-related product during playing online video game. Gamers usually spend time and money on virtual product such as clothes for avatar characters, weapons for fighting, and potions for healing teammates in the game. If that so, video games have reached a level of sophistication and competitiveness that not only can gamers make a living playing them, they can make a comfortable living (Kwak et al., 2005).

Multiplayer Online Battle Arena (MOBA) is one of the most widely played digital game groups in the world (Eskasasnanda, 2017). This game form is a massive multiplayer with an precision and detailed virtual world, surrounded by visual and auditory stimuli that create a remarkable virtual experience for gamers. In MOBA players fight with each other in the arena environment, and the gameplay is focused on tactical battles. Strategy is more focused on developing character skills and strategy in battles between teams in the arena (Marcal \& Sicilia, 2018). So it is important to buy in-game virtual product to improve gamers performance, enjoyment, uniqe persona and win the competition. Virtual product traded in the MOBA include equipment, tournament items or prizes for teams. In-game micro transactions are purchases that can be made through players in the game that can affect the player's performance (functional benefits) or only provide cosmetic changes (ornamental benefits) (Schwartz, 2011).

It can be said that gamers have become a potential consumer segment in the modern economy. Therefore, marketers and game developers need to understand the behavior gamers related of buying intentions that occur during virtual experience and interaction in computer-mediated environments, such as a sense of physical presence (immersion) and the presence of psychologies (telepresence).

This research aims to analyse the effect of virtual experience through audio-visual stimuli on the game to the buying intention virtual product during playing game by adolescents who become MOBA gamers in Indonesia. Venkatesh and Bala (2008) state that virtual experiences consist of clear psychological, involvement, active, and affective states that occur in individuals who interact with computer simulations. Virtual experience while visiting virtual sites is important to confirm because it is based on theoretical opinions in the Technology Acceptance Model 2 (TAM2) (Venkatesh et al., 2004); Technology Acceptance Model 3 (TAM3) (Venkatesh \& Bala, 2008) and the Unified Theory of Acceptance and Use of Technology (UTAUT) from (Venkatesh et al., 2003) which states that the experience users feel while using a technology will moderate user acceptance of both behavioral intention and actual use of the technology.

Virtual experience is explained by the capacity to provide flow, immersion and telepresence (Gutierrez \& Thalmann, 2008). Immersion is indicated to influence the intention in purchasing virtual products (Biocca et al., 2001; Oh \& Oh, 2018) Furthermore, telepresence is also indicated to influence the purchase intention of virtual products (Biocca et al, 2001; Suh \& Chang, 2006; Hussein et al., 2010; Animesh et al., 2011; Schwartz, 2011; Tong, 2017; 
Sun et al., 2019; Jang et al., 2019). Even so, there has not been found the research about virtual experience and buying intention behaviour of adolescent gamers, therefore this research tries to fills in the research gap.

\section{LITERATURE REVIEW}

\section{Virtual experience}

Virtual experiences consist of clear, engaged, active, and affective psychological states that occur in individuals who interact with computer simulations (Li et al., 2001). Virtual experience is explained by the capacity to provide immersion, tele-presence and flow (Gutierrez \& Thalmann, 2008). The immersion constructs and telepresence are considered to have reciprocal neural correlations (Klasen et al., 2012).

Among the constructs that have been linked to video game activity, telepresence often coincides with immersion (Michailidis et al., 2018). Immersion is defined as a state of feeling entered into and interacting with a virtual environment that provides continuous stimulation, a real illusion from reality to the senses (Gutierrez \& Thalmann, 2008). Whereas, telepresence is defined in the literature as a psychological state in which a user feels lost or immersed in a mediated environment, the level at which he feels psychologically "present" in a virtual environment (Witmer \& Singer, 1994).

\section{Buying intention}

Buying intention in the context of the game can be defined as the intention of the game player to buy items related to the game in the future (Wu \& Tsai, 2013). Buying in game are purchases that can be made through players in the game that can affect the player's performance (functional benefits) or only provide cosmetic changes (ornamental benefits) (Schwartz, 2011).

\section{Previous research}

Several researchers have examined virtual experiences and their impact on the behavior of technology users as consumers in the virtual world. Jung (2011), Okuneva and Patapov (2014), Hooi and Cho, (2017) has conducted research on immersion and/or telepresence as a determinant of virtual experience on buying interest behavior in video game players. Technological advances in the development of serious game designs have provided sales opportunities for virtual products in the game, which can help the functional performance of the player's character or as a cosmetic product which of course can increase the interactive and realistic game play.

The audio-visual system stimulus of the game can create a multisensory virtual experience so that it will result in a feeling of being physically present (immersion) and psychologically present (telepresence) in the game which will further encourage interest in buying virtual products. As shown in studies Biocca et al. (2001) and Oh and Oh, (2018) where immersion can affect product purchase interest. Suh and Chang (2006), Hussein et al. (2010), Animesh et al. (2011), Schwartz (2011), Tong (2017), Sun et al. (2019), and Jang et al. (2019) which states that the ability to present telepresence is able to encourage interest in product purchases, therefore:

$\mathrm{H} 1$ : Immersion has a significant effect on buying intention of virtual products by adolescent MOBA gamers.

$\mathrm{H}$ 2: Telepresence has a significant effect on buying intention of virtual product by adolescent MOBA gamers.

\section{METHODS OF RESEARCH}

\section{Research design}

The research method used in this research is explanatory research with a quantitative approach. The location of this study is in Indonesia. The reason for choosing the location is 
because the most played video games in Indonesia are MOBA games (Lande et al., 2019). This study uses data collection methods with survey methods using online questionnaires distributed to adolescent MOBA gamers through various social media gamers community in Indonesia during COVID 19 lockdown in 2020. Measurement variables using a 7-point Likert Scale.

\section{Population and sample}

The population in this study are all adolescents who have account in MOBA games members with aged at least 16 to 25 years old, not yet married, playing in the MOBA game during pandemic COVID 19. Because the size population number is unknown, Roscoe (1975) formula is used to determine the number of samples in this study, which is 116 respondents. The sampling method in this study was carried out with a purposive sampling approach.

\section{Validity and reliability test}

The test was carried out using a validity test and a reliability test on 30 respondents. If the correlation coefficient $(r)$ between question items and the total item score has a significant level below or equal to $0.05(\mathrm{a}=5 \%)$, then the question items used in the research instrument are valid. To test the level of reliability, in this study using the Alpha Cronbach formula (Suharsimi, 2006). An instrument is said to be reliable if it has a reliability coefficient of 0.6. The validity and reliability test results on 30 respondents of this study showed that all items in the questionnaire were valid and reliable and could be used at a later stage of this study.

\section{Variables and measurements}

The variables in this study consisted of exogenous variables and endogenous variables. Exogenous variables in this study consisted of Immersion (X1) and Telepresence (X2). The endogenous variable in this study is Purchase Intention $(Y)$ in the virtual product in game microtransaction. To measure immersiveness in this study Slater and Wilbur (1997) and Ermi and Mäyrä (2005) research were used which consist of challenge based immersion (X1.1), system based immersion (X1.2) and imagination based immersion (X1.3). This study measures telepresence in the virtual experience, using the indicator from Spatial Presence Questionnaire MEC-SPQ, (Vorderer et al., 2004), i.e. self-location (X2.1) and possible action (X2.2). In addition, this study uses indicator form Souza and Freitas (2017) to measure intention purchase of virtual product in-game microtransactions which include search of recommendation ( $\mathrm{Y}$ 1.5), spending money (Y1.2), planning ( $\mathrm{Y} 1.3)$, prediction (Y1.4) and hoping to buy game item soon (Y1.5).

\section{Data analysis methods}

Inferential statistics aim to test the conceptions stated in the research hypothesis (Ferdinand, 2006). In accordance with the hypothesis that has been formulated, then in this study the analysis of the data used is Partial Least Square (PLS) with SmartPLS software.

\section{RESULTS AND DISCUSSION}

By taking into account the path coefficient of Partial Least Square (PLS) analysis using bootstrapping iteration, Figure 1 presents the results of the hypothesis testing in this study. Based on Figure 1 it is known that the relationship between constructs tested has a significant effect on the significance of $10 \%$ shown by the black arrow lines. Whereas the relationship between constructs that have non-significant effects is indicated by the red arrow line. 
Eurasia: Economics \& Business, 2(44), February 2021

DOI https://doi.org/10.18551/econeurasia.2021-02

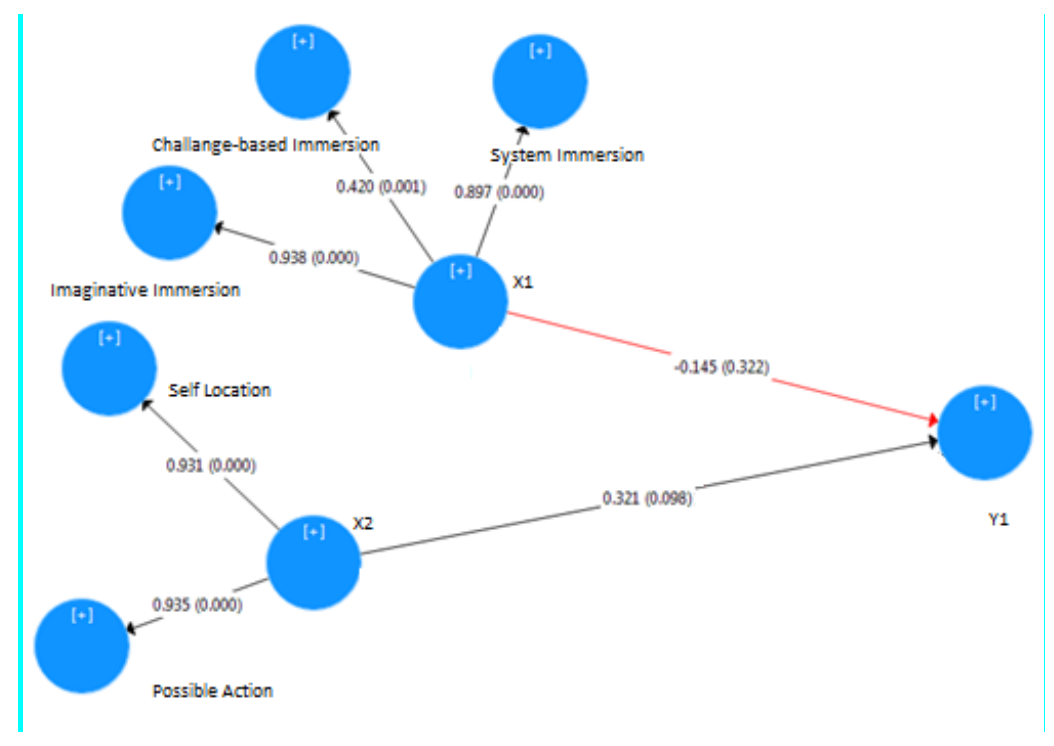

Figure 1 - Hypothesis testing model results

\section{Model and accuracy test results}

As shown in table 1, the outer test results show convergent validity is more than 0.5 , which means its validity can be accepted. This research used Cronbach's Alpha. This value reflects the reliability of all indicators in the model. The minimum value is 0.7 while the ideal is 0.8 or 0.9 . Outer test results indicate reliability is met. Whereas in this study for the inner model, the value of Q2> 0 shows evidence that the observed values have been reconstructed properly so that the model has predictive relevance.

Table 1 - Test results of outer and inner models

\begin{tabular}{|c|c|c|c|c|c|}
\hline $\begin{array}{l}\text { Measurement } \\
\text { Model }\end{array}$ & & Result & & $\begin{array}{l}\text { Rule of } \\
\text { Thumb }\end{array}$ & Notes \\
\hline \multirow{16}{*}{$\begin{array}{l}\text { Convergent } \\
\text { Validity }\end{array}$} & \multicolumn{3}{|c|}{ Outer Model } & & \\
\hline & Notation & Item & $\begin{array}{l}\text { Loading } \\
\text { Factor }\end{array}$ & \multirow{15}{*}{$\geq 0.500$} & \multirow{15}{*}{ Good } \\
\hline & $\mathrm{X} 1.1 .1$ & $\begin{array}{l}\text { Games provide mental challenges } \\
\text { during gameplay. }\end{array}$ & 0,865 & & \\
\hline & $\mathrm{X} 1.1 .2$ & $\begin{array}{l}\text { The game provides motoric } \\
\text { challenges during gameplay. }\end{array}$ & 0,866 & & \\
\hline & X.1.1.3 & $\begin{array}{l}\text { Games have a goal that is challenging } \\
\text { to achieve. }\end{array}$ & 0,813 & & \\
\hline & $\mathrm{X} 1.2 .1$ & $\begin{array}{l}\text { Allows interacting with virtual objects } \\
\text { in the game. }\end{array}$ & 0,892 & & \\
\hline & $\mathrm{X} 1.2 .2$ & $\begin{array}{l}\text { There are various visual forms in the } \\
\text { game. }\end{array}$ & 0,821 & & \\
\hline & $\mathrm{X} 1.2 .3$ & Clarity of in-game information content & 0,824 & & \\
\hline & $\mathrm{X} 1.3 .1$ & $\begin{array}{l}\text { Feel the virtual environment in the } \\
\text { game as if it were real }\end{array}$ & 0,726 & & \\
\hline & $\mathrm{X} 1.3 .2$ & $\begin{array}{l}\text { It was as if imagination and reality } \\
\text { could not be distinguished }\end{array}$ & 0,834 & & \\
\hline & $\mathrm{X} 1.3 .3$ & $\begin{array}{l}\text { Feel like playing a character in a } \\
\text { game with great inspiration. }\end{array}$ & 0,718 & & \\
\hline & $\mathrm{X} 2.1 .1$ & $\begin{array}{l}\text { During the game feel in a real } \\
\text { environment. }\end{array}$ & 0,891 & & \\
\hline & $\mathrm{X} 2.1 .2$ & Feeling part of the exploration. & 0,953 & & \\
\hline & $\mathrm{X} 2.1 .3$ & $\begin{array}{l}\text { Feel as if involved in an in-game } \\
\text { presence. }\end{array}$ & 0,944 & & \\
\hline & $\mathrm{X} 2.2 .1$ & $\begin{array}{l}\text { Virtual objects in the game can be } \\
\text { actively involved to help with game } \\
\text { performance. }\end{array}$ & 0,939 & & \\
\hline & $\mathrm{X} 2.2 .2$ & $\begin{array}{l}\text { Feel able to move actively in a virtual } \\
\text { game environment. }\end{array}$ & 0,770 & & \\
\hline
\end{tabular}


Eurasia: Economics \& Business, 2(44), February 2021

DOI https://doi.org/10.18551/econeurasia.2021-02

\begin{tabular}{|c|c|c|c|c|c|}
\hline & $\mathrm{X} 2.2 .3$ & $\begin{array}{l}\text { Feel like can do anything in a virtual } \\
\text { game environment. }\end{array}$ & 0,923 & & \\
\hline & Y1.1 & $\begin{array}{l}\text { Will recommend to virtual product } \\
\text { friends in the game. }\end{array}$ & 0,846 & & \\
\hline & Y1.2 & $\begin{array}{l}\text { Most likely will spend money to buy } \\
\text { virtual products in the game. }\end{array}$ & 0,737 & & \\
\hline & Y1.3 & $\begin{array}{l}\text { Intend to purchase virtual products in } \\
\text { the game in the future. }\end{array}$ & 0,776 & & \\
\hline & Y1.4 & $\begin{array}{l}\text { Imagine using the virtual game } \\
\text { product during the game. }\end{array}$ & 0,813 & & \\
\hline & Y1.5 & $\begin{array}{l}\text { Hope to buy virtual products in the } \\
\text { game as soon as possible }\end{array}$ & 0,750 & & \\
\hline \multirow{4}{*}{$\begin{array}{l}\text { Cronbach } \\
\text { Alpha }\end{array}$} & Notation & Variable & $\begin{array}{l}\text { Cronbach } \\
\text { Alpha }\end{array}$ & \multirow{4}{*}{$\geq 0.700$} & \multirow{4}{*}{ Good } \\
\hline & $\mathrm{X} 1$ & Immersion & 0.807 & & \\
\hline & $\mathrm{X} 2$ & Telepresence & 0.857 & & \\
\hline & Y1 & Buying Intention & 0.939 & & \\
\hline \multicolumn{6}{|c|}{ Inner Model } \\
\hline \multirow{4}{*}{ Q Square } & Notation & Variable & Relevance & \multirow{4}{*}{$\mathrm{Q}^{2}>1$} & \multirow{4}{*}{ Good } \\
\hline & $\mathrm{X} 1$ & Immersion & 1.000 & & \\
\hline & $\mathrm{X} 2$ & Telepresence & 1.000 & & \\
\hline & Y1 & Buying Intention & 1.000 & & \\
\hline
\end{tabular}

\section{Hypothesis test results}

Based on the results of hypothesis testing using PLS bootstrapping resampling with a value of $\alpha 10 \%$, the results of hypothesis testing are as follows on Table 2 . Hypothesis 1 states that immersion has no significant effect on buying intention. The calculation results show the value of $p$ value $(0.322)>0.1$ means a significant effect (at the level of $10 \%$ ), so H1 is rejected. Therefore, hypothesis 1 which states that Immersion has a significant effect on Purchase Intention cannot be accepted. By rejecting this hypothesis, it can be said that there is not enough empirical evidence to accept hypothesis 1.

However, hypothesis 2 states that telepresence has a significant effect on buying intention. The calculation results show the $p$ value $(0.098)<0.1$ means a significant effect (at the level of $10 \%)$. Therefore, hypothesis 2 can be accepted. In addition, it can be concluded that the relationship between the two is positive and unidirectional, i.e. the better telepresence that is felt will further increase the intention in the purchase of game product by adolescent MOBA gamers. With the rejection of the hypothesis, it can be said that there is sufficient empirical evidence to accept hypothesis 2.

Table 2 - Hypothesis test results

\begin{tabular}{|c|c|c|c|c|c|c|}
\hline Hypothesis & Original Sample (O) & Sample Mean (M) & Standard Deviation (STDEV) & T Statistics $(|\mathrm{O} / \mathrm{STDEV}|)$ & $\mathrm{P}$ Values & Result \\
\hline$X 1 \rightarrow Y$ & -0.145 & -0.202 & 0.314 & 0.463 & 0.322 & $\begin{array}{l}\text { Not } \\
\text { Sig }\end{array}$ \\
\hline $\mathrm{X} 2 \rightarrow \mathrm{Y}$ & 0.0321 & 0.354 & 0.248 & 1.293 & 0.098 & Sig \\
\hline
\end{tabular}

Immersion has no significant effect on buying intention. The results of this study are contradictory to the results of experimental research by Biocca et al. (2001) of undergraduate students in Arizona that show immersion has a significant and positive effect on buying intention in 3D virtual environments. In addition, the results of this study are also contrary to the results of research by Oh and Oh (2018) at the visitor event exhibition that applied virtual reality in Seoul where their research results show the immersion ability of technology can encourage the purchase intention of a product. But this unsignificant results of this study have been predicted by Sun et al. (2019) research on consumers in China who have shopped through shopping platforms and live streaming which states immersion due to the 
low legibility of product information on VR live streaming resulting in low product purchase interest.

The result can be caused by the system that used in game commonly semi or even low immersion technologies especially for PC and mobile version, thus players not really feel the immersive graphic and spherical view in the virtual environment. This also can be due to the majority of respondents involved in this study having a high school education level/equivalent, this can be mean that average intelligence relate causes MOBA has a simple concept of playing and easy to understand, ease of solving game challenges, systems that are not complicated capital knowing a goal to destroy the opposing team's headquarters, players can easily win the game just by the mindset of strengthening their own character. In this study respondents generally accept the standard and lack of a graphical display of persona/avatar games and relying on supporting content that is available free in a virtual environment of MOBA game.

On the other hand, telepresence has a significant effect on buying intention. The results of this study indicate that telepresence consists of feeling that they have moved locations themselves and the possibility to take action in a virtual game environment has been able to encourage the creation of intention in buying content in game transactions. In addition, it can be concluded that the relationship between the two is positive and unidirectional, i.e. the better telepresence that is felt will further increase the intention in the purchase of game content by adolescent MOBA gamers. This supports the research findings of Tong (2017), which conducted research on consumers who have watched live video broadcasts when they shop on e-commerce platforms, where the results of this research show that telepresence from live video broadcast marketing is able to encourage the creation of purchase intention of e-commerce products the. The results of this study are also in line with research Biocca et al. (2001), Suh and Chang, (2006), Hussein et al. (2010), Animesh et al. (2011), Schwartz (2011), Sun et al. (2019), Jang et al. (2019) which state that telepresence has a significant and positive effect on the intention in making purchases, especially in e-commerce.

Respondents rated the ability to be able to move actively in a virtual environment as the most important value (highest mean). This shows that the imaginary ability of graphics, challenges and complex systems (in immersion) is not very important but the most important is the ability of the virtual environment to provide active movement capabilities so that they do not feel rigid and physically and psychologically free during the game play. This is further considered to be able to influence the possibility of athletes to buy in-game content (cosmetics/additional accessories) to support getting a deeper sense of telepresence during game play. MOBA is very oriented towards teamwork. With the characteristics and general purpose of the MOBA game genre, the ability to actively move will be very necessary and the level of ease for customizing player characters in the game is very possible so that players can buy in-game content (additional accessories) to support active movement in the game.

In general, this study strengthens the theoretical opinion of Technology Acceptance Model 2 (TAM2) (Venkatesh et al., 2004); Technology Acceptance Model 3 (TAM3) (Venkatesh \& Bala, 2008) and the Unified Theory of Acceptance and Use of Technology (UTAUT) from (Venkatesh et al., 2003). To get a better understanding of the use of the virtual environment and its impact on the buying intention behavior of adolescent gamers where the experience while visiting the virtual environment plays an important role in it, especially the experience of psychological presence (telepresence) (Venkatesh et al., 2004)

\section{CONCLUSION}

The results of this study indicate that the immersion of challenges, the immersion of the system and the immersion of imagination that shape the immersion during game play have not been able to fully encourage the creation of an interest in purchasing in-game content of adolescent MOBA gamers in Indonesia during COVID 19 outbreaks. The results of this study indicate that telepresence consists of feeling that they have moved locations themselves and 
the possibility to take action in a virtual game environment has been able to encourage the creation of interest in buying virtual product in game.

This research shows that gaming companies and game designers need to consider the ability of the game to provide psychological presence because it has been confirmed in this research that telepresence is proven to be able to encourage the creation of buying intention virtual product in-game microtransaction. Meanwhile, the graphics and physical presence (immersion) of the MOBA game are not necessary affect the consumer behaviour in-game, as predicted in research of Sun et al. (2019). The result can be caused by the system that used in game commonly semi or even low immersion technologies especially for desktop and mobile version, thus players not really feel the immersive graphic and spherical view in the virtual environment.

Moreover, a key practical implication of our study is that serious game system developer need to pay special attention to the current state of technology when designing cutting edge game and devices in the further, the application of fully immersion system during game play is recommended to support physical presence. This study contributes to literature on virtual experience adoption research by introducing a research model for buying behaviour in virtual product of adolescents. Furthermore, researchers can then analyze the effect of flow on in game purchase decisions Gao and Bai (2014), Richard and Chebat (2016), Fujiwara (2018) and Molinillo et al. (2018) to complete the analysis of virtual experiences offered in the game, especially considering the pandemic condition is apparently still continuing.

\section{Competing interests}

The authors declare that they have no competing interests.

\section{Authors' contributions}

ASB designed, conceived of the study and coordinated this research. MRH carried out survey and data analysis, drafted the manuscript and participated in research coordination. The authors read and approved the final manuscript.

\section{Acknowledgements}

The researcher would like address their sincere gratitude to Universitas Brawijaya, Indonesia and then for all of Indonesian adolescent MOBA gamers who have been willing to become respondents and gamers community that has supported the data collection.

\section{Funding}

This research was funded with DIPA BLU funds by University of Brawijaya, Indonesia based on a Contract Letter Number: DIPA-042.01.2.400919/2020.

\section{REFERENCES}

1. Animesh, A., Pinsonneault, A., \& Oh, W. (2011). An Odyssey into Virtual Worlds: Exploring the Impacts of Technological and Spatial Environments on Intention to Purchase Virtual Products. MIS Q, 35(3), 789-810.

2. Bilgihan, A., Karadag, E., Cobanoglu, C., \& Okumus, F. (2013). Research note: biometric technology applications and trends in hotels. FIU Hospitality Review, 31(2).

3. Biocca, F., Daugherty, T., \& Chae, Z. H. (2001). Effect of visual sensory immersion on presence, product knowledge, attitude toward the product and purchase intention. In Proceedings of the Experiential E-Commerce Conference. Est Lansing: Michigan State University.

4. Björklid, P., \& Nordström, M. (2007). Environmental Child-Friendliness: Collaboration and Future Research. Children, Youth and Environments, 17(4), 389- 401.

5. Boterman, W. R., Karsten, L., \& Musterd, S. (2010). Gentrifiers Settling Down? Patterns and Trends of Residential Location of Middle-Class Families in Amsterdam. Housing Studies, 25(5), 693-714. 
6. Brooks, F. M., Chester, K. L., Smeeton, N. C., \& Spencer, N. H. (2015). Video gaming in adolescence: factors associated with leisure time use. Journal of Youth Studies, 19(1), 36-54.

7. Carver, A., Timperio, A., Hesketh, K., \& Crawford, D. (2010). Are children and adolescents less active if parents restrict their physical activity and active transport due to perceived risk? Social Science \& Medicine, 70(11), 1799-1805. doi:10.1016/j.socscimed.2010.02.010.

8. Clements, R. (2004). An investigation of the State of Outdoor Play. Contemporary Issues in Early Childhood, 5, 68-80.

9. De Souza, L. L. F., \& de Freitas, A. A. F. (2017). Consumer behavior of electronic games' players: a study on the intentions to play and to pay. Revista de Administração, 52(4), 419-430.

10. Denegri-Knott, J., \& Molesworth, M. (2010). Digital virtual consumption: Concepts and practices. Consumption Markets and Culture, 13(2), 109-132.

11. Ermi, L., \& Mäyrä, F. (2005). Fundamental components of the gameplay experience: Analysing immersion. Worlds in play: International perspectives on digital games research, 37(2), 37-53.

12. Eskasasnanda, I. D. P. (2017). Causes and Effects of Online Video Game Playing among Junior-Senior High School Students in Malang East Java. Komunitas: International Journal of Indonesian Society and Culture, 9(2), 191-202.

13. Eventbrite. (2014). The eSports Effect: Gamers and the Influence of Live Events. Retrieved from https://www.eventbrite.com/blog/academy/the-esports-effect-gamers-andthe-influence-of-live-events/

14. Ferdinand, A. T. (2006). Metode Penelitian Manajamen. Semarang: Badan Penerbit Universitas Diponegoro.

15. Fujiwara, A. (2018). Evaluating the influence of music on shoppers' flow in an online fashion retail environment (Doctoral Dissertation). Nottingham Trent University, UK.

16. Gao, L., \& Bai, X. (2014). Online consumer behaviour and its relationship to website atmospheric induced flow: Insights into online travel agencies in China. Journal of Retailing and Consumer Services, 21(4), 653-665.

17. Griffiths, M., Davies, M. N., \& Chappell, D. (2004). Online computer gaming: a comparison of adolescent and adult gamers. Journal of Adolescence, 27(1), 87-96.

18. Gutierrez, M., Vexo, F., \& Thalmann, D. (2008). Stepping into virtual reality. Switzerland: Springer.

19. Hussein, Z., Wahid, N. A., \& Saad, N. (2010). Evaluating Telepresence Experience and Game Players' Intention to Purchase Product Advertised in Advergame, Int. J. Soc. Behav. Educ. Econ. Bus. Ind. Eng, 4(6), 1365-1370.

20. Hooi, R., \& Cho, H. (2017). Virtual world continuance intention. Telematics and Informatics, 34(8), 1454-1464.

21. Jang, J. Y., Hur, H. J., \& Choo, H. J. (2019). How to evoke consumer approach intention toward VR stores? Sequential mediation through telepresence and experiential value. Fashion and Textiles, 6(1), 12.

22. Jung, Y. (2011). Understanding the role of sense of presence and perceived autonomy in users' continued use of social virtual worlds. Journal of Computer-Mediated Communication, 16(4), 492-510.

23. Jurczyk, K., \& Lange, A. (2007). Blurring boundaries of family and work. Challenges for children. In H. Zeiher \& D. Devine (Eds.), Flexible childhood? Exploring children's welfare in time and space (pp. 215-238). Odense: University Press of Southern Denmark

24. Karsten, L. (2005). It All Used to Be Better? Different Generations on Continuity and Change in Urban Children's Daily Use of Space. Children's Geographies, 3(3), 275-290.

25. Kepper, M. M., Staiano, A. E., Katzmarzyk, P. T., Reis, R. S., Eyler A. A., \& Griffith D. M. (2020). Using mixed methods to understand women's parenting practices related to their child's outdoor play and physical activity among families living in diverse neighborhood environments. Health Place, 62(102292), 1-10. 
26. Klasen, M., Weber, R., Kircher, T. J., Mathiak, K. A. \& Mathiak, K. (2012). Neural contributions to flow experience during video game playing. Social cognitive and affective neuroscience, 7(4), 485-495.

27. Kuntsche, E., Simons-Morton, B., Ter Bogt, T., Sa'nchez Queija, I., Muñoz Tinoco, V., Gaspar de Matos, M., Santinello, M., \& Lenzi, M. (2009). Electronic media communication with friends from 2002 to 2006 and links to faceto-face contacts in adolescence: an HBSC study in 31 European and North American countries and regions. Int J Public Health, 54, 243-250.

28. Kuss, D. J., \& Griffiths, M. D. (2012). Internet gaming addiction: A systematic review of empirical research. International Journal of Mental Health and Addiction, 10(2), 278-296.

29. Kwak, N., Williams, A., Wang, X., \& Lee, H. (2005). Talking politics and engaging politics: An examination of the interactive relationships between structural features of political talk and discussion engagement. Communication Research, 32(1), 87-111.

30. Kyttä, M. (2004). The Extent of Children's Independent Mobility and the Number of Actualized Affordances as Criteria for Child-Friendly Environments. Journal of Environmental Psychology, 24(2), 179-198.

31. Li, H., Daugherty, T., \& Biocca, F. (2001). Characteristics of virtual experience in electronic commerce: A protocol analysis. Journal of Interactive Marketing, 15(3), 13-30.

32. López-Cabarcos, M. Á., Pérez-Pico, A. M., Piñeiro-Chousa, J., \& Šević, A. (2020). Bitcoin volatility, stock market and investor sentiment, are they connected? Finance Research Letters, doi:10.1016/j.frl.2019.101399.

33. Marçal, M. C., \& Sicilia, M. Á. (2018). MOBA games: A literature review. Entertainment computing, 26, 128-138.

34. Michailidis, L., Balaguer-Ballester, E., \& He, X. (2018). Flow and immersion in video games: The aftermath of a conceptual challenge. Frontiers in Psychology, 9(1682).

35. Molinillo, S., Liébana-Cabanillas, F., \& Anaya-Sánchez, R. (2018). A social commerce intention model for traditional e-commerce sites. Journal of theoretical and applied electronic commerce research, 13(2), 80-93.

36. Oh, S. H., \& Oh, J. W. (2018). The Influence of Servicescape of Exhibition on the Visitors Immersion and Revisit Intention, Int. J. Pure Appl. Math, 118(19), 1703-1715.

37. Okuneva, M., \& Potapov, D. (2014). Consumer behavior in online games. Higher School of Economics Research Paper No. WP BRP 25.

38. Olson, C. K. (2010). Children's Motivations for Video Game Play in the Context of Normal Development. Review of General Psychology, 14(2), 180-187.

39. Olson, C. K., Kutner, L. A., Warner, D. E., Almerigi, J. B., Baer, L., Nicholi, A. M., \& Beresin, E. V. (2007). Factors Correlated with Violent Video Game Use by Adolescent Boys and Girls. Journal of Adolescent Health, 41(1), 77-83.

40. Richard, M. O., \& Chebat, J. C. (2016). Modeling online consumer behavior: Preeminence of emotions and moderating influences of need for cognition and optimal stimulation level. Journal of Business Research, 69(2), 541-553.

41. Roscoe, J. T. (1975). Fundamental research statistics for the behavioral sciences. New York: Holt.

42. Saurabh, K., \& Ranjan, S. (2020). Compliance and Psychological Impact of Quarantine in Children and Adolescents due to Covid-19 Pandemic. Indian J. Pediatr, 87, 532-536.

43. Schwartz, A. M. (2011). Augmenting purchase intent: an empirical study on the effects of utilizing augmented reality in online shopping. Available at SSRN 1858976.

44. Slater, M., \& Wilbur, S. (1997). A framework for immersive virtual environments (FIVE): Speculations on the role of presence in virtual environments. Presence: Teleoperators \& Virtual Environments, 6(6), 603-616.

45. Sun, Y., Shaoa, X., Lic, X., Guod, Y., \& Niea, K. (2019). How live streaming influences purchase intentions in social commerce: An IT affordance perspective. Electron. Commer. Res. Appl, 37, 1-12.

46. Suh, K. S., \& Chang, S. (2006). User interfaces and consumer perceptions of online stores: The role of telepresence. Behaviour \& information technology, 25(2), 99-113. 


\section{Eurasia: Economics \& Business, 2(44), February 2021}

DOI https://doi.org/10.18551/econeurasia.2021-02

47. Suharsimi, A. (2006). Prosedur penelitian suatu pendekatan praktik. Jakarta: Rineka Cipta.

48. Tong, J. (2017). A study on the effect of web live broadcast on consumers' willingness to purchase. Open Journal of Business and Management, 5(02), 280.

49. Tull, M. T., Edmonds, K. A., Scamaldo, K. M., Richmond, J. R., Rose, J. P., \& Gratz, K. L. (2020). Psychological outcomes associated with stay-at-home orders and the perceived impact of COVID-19 on daily life. Psychiatry Res. 289(113098).

50. Venkatesh, V., \& Bala, H. (2008). Technology acceptance model 3 and a research agenda on interventions. Decision sciences, 39(2), 273-315.

51. Venkatesh, V., Morris, M. G., Davis, G. B., \& Davis, F. D. (2003). User acceptance of information technology: Toward a unified view. MIS quarterly, 425-478.

52. Venkatesh, V., Morris, M. G., Sykes, T. A., \& Ackerman, P. L. (2004). Individual reactions to new technologies in the workplace: The role of gender as a psychological construct. Journal of Applied Social Psychology, 34(3), 445-467.

53. Vorderer, P., Wirth, W., Gouveia, F. R., Biocca, F., Saari, T., Jäncke, F., \& Klimmt, C. (2004). MEC spatial presence questionnaire (MEC-SPQ): Short documentation and instructions for application. Report to the European community, project presence: MEC (IST-2001-37661), 3, 5-3.

54. Witmer, B. G., \& Singer, M. J. (1994). Measuring immersion in virtual environments. ARI Technical Report 1014). Alexandria, VA: US Army Research Institute for the Behavioral and Social Sciences.

55. Wu, C. S., \& Tsai, L. F. (2013). The research on relationship among online game endorsement, adolescent involvement and game purchase intention. International Journal of Management, Economics and Social Sciences, 2(3), 205-216.

56. Zhu, L. (2020). The psychology behind video games during COVID-19 pandemic: A case study of animal crossing: New horizons. Human Behavior and Emerging Technologies, $3(1)$. 